Featured Article

\title{
What Are the Role and Impact of Public-Private Partnerships in Education? A Realist Evaluation of the Chilean Education Quasi-Market
}

\author{
ANTONI VERGER, XAVIER BONAL, AND ADRIÁN ZANCAJO
}

\begin{abstract}
The superiority of market mechanisms in educational provision is a premise that has received renewed emphasis under the regime of public-private partnerships (PPPs). The central idea of PPPs - enthusiastically embraced by a range of international organizations, development agencies and scholars - is grounded in the assumption that competition between public and private schools is an effective means of promoting education quality and efficiency. PPP policy frameworks are expected to establish genuine market dynamics in which suppliers innovate and boost the quality of their education services as a way to attract families, who are portrayed as benefit maximizers and well-informed consumers. The application of these market ideas to education, however, has suffered from a series of modifications and failures under real world conditions. This study is based on the case of Chile - the most market-oriented education system in the world — and examines how few of the taken-for-granted benefits of market-oriented provision either have been or can be fulfilled, due to the nature of the supply structure and to the effects of agents' expectations and behaviors.
\end{abstract}

\section{Introduction}

Public-private partnerships (PPPs) in education are portrayed as a costeffective policy solution to the access and quality problems that many education systems, especially in developing countries, currently face (Patrinos et al. 2009; Chattopadhay and Nogueira 2013). The primary objective of PPPs is to promote competition for resources between private and public schools as a means for enhancing the quality and effectiveness of education systems. School

We are very grateful to the Comparative Education Review coeditors and to three anonymous referees for their insightful and constructive comments. The research presented in this article has been supported by the projects "Public-Private Partnerships in Educational Governance: An Analysis of Its Dissemination, Implementation and Impact in a Globalizing World” (EDUPARTNER, Ref. GA-2012-322350, EU Program "PEOPLE") and "Cuasi-mercados en educación en América Latina: Un análisis de su implementación e impacto sobre la desigualdad y la pobreza” (EDUMERCAL, Ref. CSO2011-22697, Spanish Ministry of Education).

Received July 30, 2014; revised May 4, 2015, July 30, 2015, and September 2, 2015; accepted September 24, 2015; electronically published March 28, 2016

Comparative Education Review, vol. 60, no. 2.

(c) 2016 by the Comparative and International Education Society. All rights reserved.

0010-4086/2016/6002-0001\$10.00 
choice is seen as a central mechanism to this end. As argued in the well-known World Bank report The Role and Impact of PPPs in Education: "The idea is that parents choose the best school for their children on the grounds of quality, which in turn puts pressure on schools to compete to attract students and to achieve better academic results at a lower cost" (Patrinos et al. 2009, 61). According to this same report, providing people with choice and exit opportunities may especially benefit "marginalized groups and the poor, who are ill-served by traditionally delivered public services" (6).

Despite the recent application of this particular meaning of "PPPs" in the education field - that is, as a policy framework that triggers school choice and competition-the specific policy instruments that countries are expected to adopt in developing PPPs in education, such as vouchers or out-contracting of services, are far from new. In fact, the concept of PPPs in education has many resemblances to the public sector reform programme that public choice theorists have been advocating for decades, as well as to what social scientists have traditionally termed "quasi-markets" in education (see Glennerster 1991; Le Grand 1991)

Existing research on quasi-markets, vouchers, and school competition has not reached clear conclusions concerning the costs and benefits of these policies, although it usually raises education equity concerns (Waslander et al. 2010; OECD 2012). Despite full awareness of the evidence (or of its absence), influential international organizations and transnational consultancy firms are actively disseminating PPP solutions across a broad range of practice communities (Verger 2012; Lubienski 2014). They see school competition within PPP frameworks as a sort of magic bullet that, once governments have addressed the necessary regulatory issues, has the potential to promote access and improve learning outcomes in very diverse educational settings.

The wide diffusion of PPP solutions in education that we are witnessing today is related, to a great extent, to the material power of its promoters, as well as to the power of the "market metaphor" in public sector reform. Market metaphors are inherently persuasive due to their capacity to reduce the complexity of educational problems and solutions to a few simple nostrums: for example, schools competing for students and resources are key drivers of educational change and excellence. Policy messages based on market metaphors are also powerful because most policy makers have long experience with "the market" as a space for the distribution of a range of goods and services in their daily lives. Despite the elegance and persuasiveness of the market model, we argue that its application faces numerous obstacles in real educational settings.

Our main objective in this article is to explain how quasi-markets work in the education sector and to assess the extent to which related policies in fact generate new educational opportunities for the poor or, on the contrary, exacerbate existing educational inequalities. To achieve this objective, we fo- 
cus on the case of Chile, the country that has embraced quasi-markets in education for the longest period and on the largest scale. Methodologically speaking, we develop and apply a "realist evaluation" framework (see Pawson 2006) for assessing the worth of the policy. In fact, the first part of the article is devoted to presenting the core principles of a realist evaluation methodology and outlining the advantages of adopting such an approach as opposed to more conventional evaluation methods. We argue that realist evaluation is especially appropriate for analyzing education policies whose implementation depends so decisively on the strategic behavior, "logics of action" (see Ball and Maroy 2009) and preferences of the intended beneficiaries of the intervention-clearly the case for PPPs in education.

A key step in developing a realist evaluation lies in systematically articulating the main theoretical assumptions on which the policy to be analyzed is grounded - what Pawson (2006) calls its "program ontology." To a great extent, the theoretical roots of PPPs in education can be traced to public choice theory, which is why we dedicate the second section of this article to identifying the main premises in this theory and relating them to the core elements in the design of PPPs in education.

In the third section, we present briefly the main features of the Chilean education system, especially those that more clearly fit the PPP program ontology; and in the fourth, we present the methods and the empirical strategy followed by the study that we conducted in Chile. In the fifth section, we analyze our data according to two of the most fundamental assumptions of PPP models: first, on the demand side, the assumption that information allows choices based on quality criteria and that these choices are the key factor in promoting school competition; and then, on the supply side, the premise that school competition promotes educational quality and school diversification and innovation.

Finally, we conclude by discussing our results and identifying the main policy lessons offered by a realist evaluation of the application of public choice theory assumptions to Chilean education.

\section{A Realist Evaluation Framework for Analyzing Education Quasi-Markets}

The analysis of the implementation and impact of PPPs - and quasi-market policies, more broadly speaking - is a particularly contentious area of study. Existing research on the subject is puzzling in the sense that the interpretation of data often yields highly contradictory conclusions. The range of methodological options most used in these studies is eminently quantitative, varying from experiments with random samples and control groups to propensity score matching and regression discontinuity analysis (Patrinos et al. 2009). The dependent variable that predominates in this sort of study is student learning, as measured by standardized testing. Some studies conclude 
that PPP interventions have significant impacts on levels of learning (Wößmann 2006; Chakrabarti and Peterson 2009), while others claim that there are few effects or that the impact is minimal at best (Rouse and Barrow 2009). Regarding other success criteria as cost-effectiveness, the literature is also remarkably contradictory. Some researchers conclude that greater school competition makes public schools more productive and efficient (Hoxby 2000), while others suggest that market mechanisms are a source of inefficiency in education systems (Levin 1999).

One of the reasons why research on PPP yields such contradictory results lies in the context-sensitivity of these policies, as well as the difficulty of capturing and controlling contextual variables within econometric models. Impact analyses of PPPs frequently attempt to understand whether "PPPs work (or not)" without paying sufficient attention to contextual issues that condition results, or simply by assuming that this type of variables can be controlled or measured through different proxies. Recent developments in policy evaluation studies can contribute, however, to challenging such a heavily positivist tradition. This is the case with "realist evaluation," a theory-driven evaluation methodology that treats policy programs (in our case, PPPs) as hypotheses about social betterment that need to be unpacked and empirically tested before we credit them with assumed impacts (Pawson 2006).

Realist evaluation is part of a "realist" social science tradition that understands social systems as the product of "endless components and forces" (Pawson 2006, 18). Researchers in this tradition recognize how challenging it is to try to exercise control over the numerous macro- and microconditions that influence the policy intervention we wish to analyze. However, by no means does this imply that we should not try to capture how "context matters" in policy processes - quite the reverse. As a methodology, realist evaluation challenges us to stop assessing interventions in a vacuum and instead to put first importance on determining "what works, for whom, in what circumstances or respects ... and how?" (Pawson and Tilley 2004, 2).

In both experimental and quasi-experimental impact evaluations it is usually taken for granted that PPPs and other policy interventions are, per se, treatment variables that necessarily alter educational results in one way or another (see Glewwe 2014). Following the premises of realist evaluation, our research takes a step back and problematizes the operations of PPP interventions themselves, not just their putative results. This entails opening up the black-box of the intervention to determine whether its constitutive mechanisms are effectively triggered by the agents involved. Whether the subjects actually go along with the theory behind the PPP intervention and use the resources as intended by its designers becomes in effect an empirical question rather than a condition that is taken for granted. Thus, instead of assuming that policy programs are automatically implemented as designed, realist evaluators always see their application as mediated by the previous ex- 
periences, values and interests of the subjects, and by the ways in which they interpret the rules of the program (Ball et al. 2012). Inevitably, some aspects of the policy interventions "will be rejected, selected out, ignored, [or] deliberately misunderstood," and subjects' responses may even look "frivolous" to the authors and proponents of the intervention (Bowe et al. 1992, 22).

Of course the realist evaluation approach has itself been the subject of criticism and is not without limitations (see Marchal et al. 2012; Porter 2015). The framework nonetheless seems particularly relevant to the analysis of policy interventions that are characterized by a complex set of agents and variables in interaction. Faced with this challenge, realist evaluators tend to consider two main sets of variables that are usually missing or poorly incorporated in econometric models: first, the local conditions in which the intervention is implemented (including the norms, regulations, and socioeconomic configuration in which the subjects are embedded); and, second, the preferences, logics of action, and strategic responses of the educational agents who take part in the intervention. Both of these factors indelibly influence the enactment and the outcomes of an intervention. Therefore, as a first step, analyzing PPPs in a realist evaluation mode involves reconstructing the "program ontology" of the intervention, which we undertake in the following section.

\section{The Premises of Public Choice Theory in Education}

The theoretical roots of PPP programs can be found in public choice theory. This theory-sometimes referred to as social choice theory or market theory (see Lubienski 2006) - is an integral part of the neoliberal approach to public policy, particularly in its prescriptive diagnosis of the pathologies of public administration (Klees 2008). Public choice theorists assume that human beings are rational and self-interested utility-maximizers and, on the basis of this core concept, construct the models that explain what they consider to be governmental failure in service provision (Mueller 1979). In fact, public choice theorists consider public institutions as inherently inefficient and incapable of effectively promoting social welfare because bureaucrats do not have the right incentives to pursue public interestedness (Buchanan and Tullock 1999).

On the basis of these assumptions, public choice theorists see markettype institutional arrangements as the best alternative to "democratic control" (see Chubb and Moe 1990) and favor deregulation of government agencies and their management as business-style enterprises in competition with other providers. Yet although public choice theory assumes the superiority of private institutions, advocates do not necessarily seek pure-market arrangements. As Levin et al. (2013) remind us, even Milton Friedman recognized that equity and social cohesion concerns may justify public funding and other 
forms of intervention in educational markets. Hence, alternatives are often premised on continued state funding to provide public goods because the potential for free-riders in some sectors could otherwise lead to an undersupply of socially desired goods such as education (Olson 1965).

The most well-known and influential transposition of public choice theory into the education policy field was authored long before the idea of PPPs gained such centrality in the global education agenda. It is found in Chubb and Moe's Politics, Markets, and America's Schools (1990). The starting point of this book is the assertion that education systems are captive to interest groups, especially teachers' unions and administrators - groups that control public resources and reorient regulations in large part to satisfy their own interests rather than those of students. They also assume that direct public provision creates inherent institutional pathologies because bureaucracies are isolated from competitive pressures and responsiveness to consumers. In fact, they consider bureaucracy as the main obstacle to school effectiveness, since it "imposes goals, structures, and requirements that tell principals what to do and how to do it - denying them the discretion they need to exercise their expertise and professional judgment, and denying them the flexibility they need to develop and operate as teams" (Chubb and Moe 1990, 187).

The solutions to these problems can be found, they maintain, in changes at the school organization level and principally involve allowing schools more autonomy and encouraging them to behave like private enterprises in a market situation: "While schools controlled only by the market are free to organize any way they want . . . an environment of competition and choice gives them strong incentives to move toward the kinds of 'effective-school' organizations that academics and reformers would like to impose on public schools. Of course, not all schools in the market will respond equally well to these incentives. But those that falter will find it more difficult to attract support, and they will tend to be weeded out in favor of schools that are better organized" (Chubb and Moe 1990, 190).

For market advocates, more private participation in education provisionand therefore less governmental provision-is virtuous in and of itself. Private schools do better than government schools because they are better organized and managed and are more responsive to competition and enjoy more autonomy to respond effectively to such competition in key areas, including the management of the teaching workforce. Accordingly, some of their key policy recommendations are to outsource the management of public schools (as in the charter model) and to encourage public schools to emulate the organizational culture of the private sector.

Yet freedom of school choice is probably the most central mechanism in quasi-market designs for education. School choice, according to market advocates, will contribute to breaking away from an excessively bureaucratic education system by granting families more power and by making schools 
more responsive and accountable to their "customers." Like most consumers in market situations, parents are expected to seek optimal achievement of their preferences by selecting the best school available, or by leaving a school with which they are dissatisfied in order to select a better one-what Chubb and Moe (1990) call "the power to switch."

To attract and/or retain clients, schools will need to provide higher quality services to innovate and to respond more quickly than their competitors to parents' preferences. Competitive pressure should therefore result as well in greater school diversification (Chubb and Moe 1990). Milton Friedman already predicted that, in a market-driven system, there will be "many more choices, there will be a whole rash of new schools that will come into existence" (1994, 101), while James Tooley considered that "product differentiation and diversity are the hallmarks of the dynamics of competition" $(1993,37)$.

Despite the apparent simplicity of the "market model," the relationship between education markets and public intervention is itself far from simple. Somewhat paradoxically, deregulating the education sector turns out to be insufficient for constructing competitive educational markets. To implement an effective quasi-market and, specifically, to promote competition in such a context, the state needs to intervene proactively - at least, in the areas of educational financing, evaluation and public information. Per capita financing policies via, for instance, voucher schemes are expected to guarantee choice opportunities for poorer families and promote interschool competition effectively. Evaluation and information policies are expected to overcome the effects of imperfect consumer information, long recognized as one of the principal obstacles to perfect competition to rule in most markets (Lawson 2009). In education, standardized evaluation of students' learning outcomes and the corresponding publication of the results (usually in rankings or league tables) are the most well-established instruments for ensuring widespread consumer information.

Figure 1 portrays the main causal mechanisms assumed by public choice theorists to determine the operation of education quasi-markets. Each arrow represents a supposed causal relationship between two processes. The processes in square boxes are those that depend directly on state intervention, whereas those included in circles depend on "market dynamics" (or supply and demand interactions). As can be seen in the figure, information and vouchers allow for parental choice - whether choice bears on the selection of preferred schools or the decision to exit from poor-quality ones. Parental choice in turn generates higher levels of school competition, which motivates increased innovation and institutional diversification (widening choices opportunities for consumer demand) and propels quality and efficiency increases in educational supply. Finally, evaluation mechanisms need to be in place to assess the quality of those providers entering the market and, more importantly, to measure schools' performance on a regular basis. Performance evaluation can 


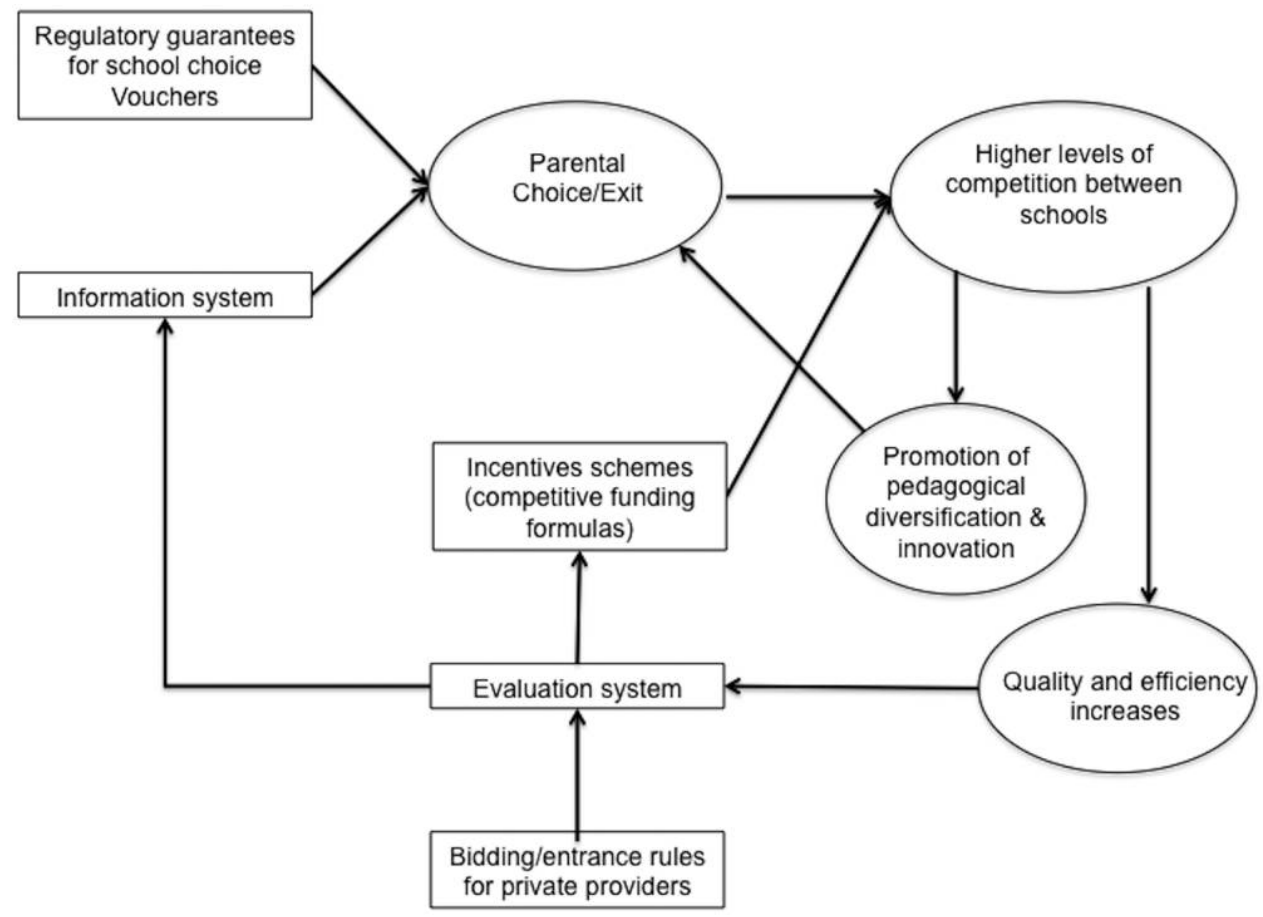

FIG. 1.-The program ontology of PPPs in education. Adapted from Verger (2012).

help nurture competitive systems of financing and, at the same time, produce the information that parents need in order to make "correct" choices. These are then the main variables in the program ontology of educational PPPs and their corresponding causal links a presumed to induce a virtuous circle.

The diagram reveals that, in the PPP program ontology, there are a significant number of assumptions and concatenated explanatory relationships that need to be unpacked and questioned.

\section{Market Mechanisms in the Chilean Education System}

Conducting empirical research on the effects of education quasi-markets is difficult because it is uncommon to find education systems in which market rules have penetrated deeply. Generalizing from the various studies on school vouchers is difficult because they are often based on experiences that have been implemented very locally, usually for a limited period and with different specific institutional designs. In fact, not every education quasi-market is suitable for relevant analyses, since "it may take some time for school choice policies to yield improvements in average academic achievement" (Patrinos 
et al. 2009, 30). Time is of the essence in judging the impact of quasi-market solutions because the different agents taking part in these complex interventions (e.g., principals, teachers, and families) need both practice and policy continuity in order to understand market rules and incorporate them into their educational decision-making behavior (Waslander et al. 2010). Chile is quite an exceptional case in this respect. The conditions in the country swamp such limitations because Chile has the longest-lasting, deepest, and broadest experience with highly deregulated educational market mechanisms of any country in the world. Those programs have been carried out on a national scale for over three decades.

In Chile, the implementation of education market policies goes back to the early eighties. The military junta that ruled the country from 1973 to 1990 under the command of the dictator Augusto Pinochet undertook major neoliberal reforms in the public sector. Education was one of the institutions most deeply transformed during that period. The cornerstone of the education reform was a drastic alteration of education financing rules and procedures. A per capita funding system with a voucher scheme was introduced as a way to ensure that educational financing followed educational demand. Choice was put at the center of educational policy. Resource allocation became dependent on the capacity of schools to compete in attracting students and - even more - on their actual attendance at schools. ${ }^{1}$ Since the introduction of the voucher system, enrollment in private schools has increased dramatically, a situation clearly illustrated in figure 2 , which shows the evolution of enrollment according to ownership at primary and secondary education levels between 1981 and 2013. ${ }^{2}$ Over these three decades, enrollment in private schools, particularly subsidized ones, increased dramatically and surpassed enrollment in public schools. In 1981, private school enrollment represented 22 percent of total enrollment, but by 2012 it was 61.2 percent, almost three times as great.

In 1994, the government approved the Law of Shared Financing as a complement to the voucher program. This regulation allows subsidized private schools to charge families fees over and beyond the amount of the school voucher provided by the government, though when the fees are high the amount of the voucher is reduced. Since its approval, this additional funding system has been a bone of controversy. While supporters claim that these extra fees provide sorely-needed additional funds to a system characterized by a low level of spending per student, critics claim that they undermine the school choice options of those poor families that cannot afford to pay the extra fees (Hsieh and Urquiola 2006; Elacqua et al. 2013).

\footnotetext{
${ }^{1}$ Transfers of funds from the government to the schools are actually based on monthly attendance, which is regularly supervised by inspection bodies.

${ }^{2}$ Corporations are a very exceptional type of vocational education schools run by private companies that receive state funding, but not through the voucher system.
} 


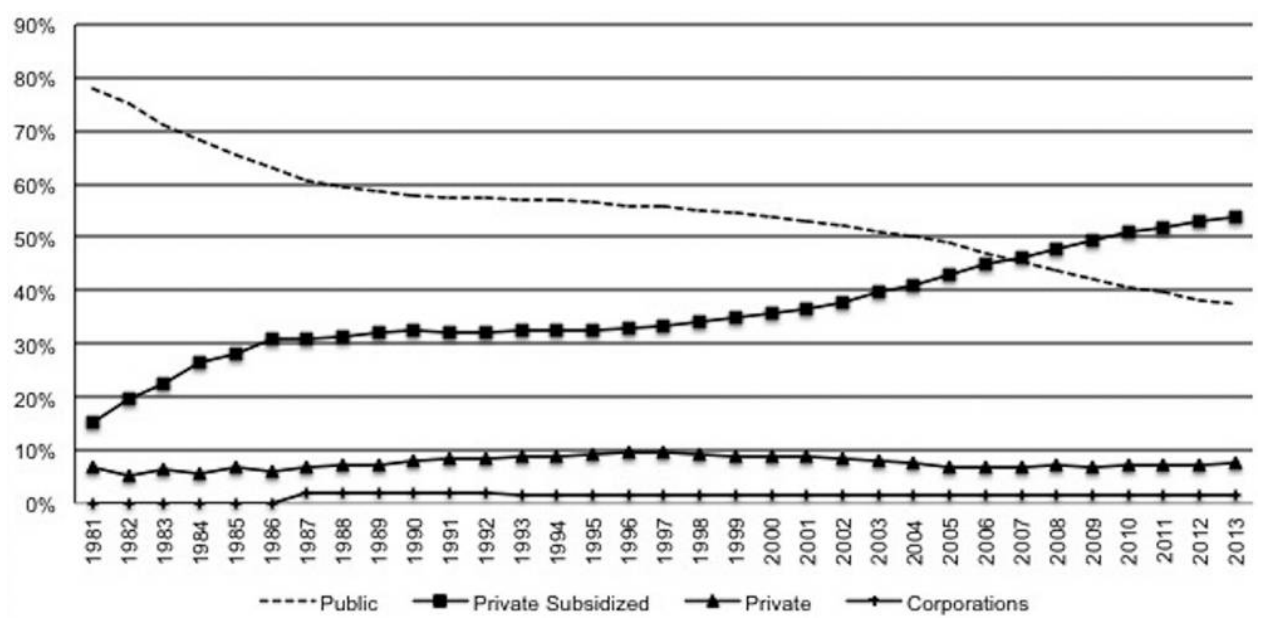

FIG. 2.-Enrollment by school type (\%), years 1981-2013. SourcE.-Authors from the Chilean Ministry of Education statistics.

The selection or "creaming" of students by schools has been a common practice in Chile, especially in the private education sector (Hsieh and Urquiola 2006; Contreras et al. 2007). However, recent legislation expressly bans selection practices for academic and socioeconomic reasons in preschool and primary education. ${ }^{3}$

Finally, another key element in the Chilean education system is the System of Quality Measurement in Education (SIMCE). This standardized national assessment of academic performance, which is administered to students in three grades in primary education and three in secondary education in eight areas of knowledge, is one of the main mechanisms designed to guide families' school choice decisions. SIMCE results are published on a yearly basis, and families can check the scores of each school and its ranking relative to others in the same geographic area. SIMCE data are also expected to promote educational competition and efficiency by serving as a benchmark for the distribution of salary incentives among teachers and providing a basis for rewarding the most productive (Mizala and Romaguera 2004).

\section{Methods and Empirical Strategy}

The realist evaluation approach adopted in this article is based on analyzing the level of compliance of the most central causal links contained in the PPPs in education program ontology - that is, the degree to which the causal assumptions built into the intervention (see fig. 1) prove actually to hold in

\footnotetext{
${ }^{3}$ See the Ley General de Educación (Law 20370) passed in 2009.
} 
practice. To achieve this purpose, we conducted a case study that focuses on the PPP dynamics in the Chilean education system. Since, like most realist evaluations, we consider that quantitative strategies are necessary but insufficient to capture the full complexity of policy interventions, our research draws on both quantitative and qualitative data.

The information analyzed derives from two different sources. On the one hand, secondary quantitative data such as historical statistics and information in the SIMCE-2011 database are used to examine the evolution of private providers, families' school selection criteria, and the enrollment requirements that schools apply. On the other hand, the qualitative data of the study come from a sample of 10 schools in a socially mixed neighborhood of the city of Valparaíso where we carried out in-depth interviews with key stakeholders between April and June 2013 to better understand the providers' logics of action and the roots of consumer behaviour. Two public schools, seven private subsidized schools, and one fully private school composed the sample-a distribution of providers types is very similar to the average distribution prevailing in Chile and particularly representative of the school system in Valparaiso. ${ }^{4}$

In each of the selected schools we carried out in-depth interviews with the principal and with two teachers, and semistructured interviews with 5-10 families with children in the first grade of ISCED-1. Families and teachers were selected randomly in each school of the sample. In total, we interviewed 10 principals, 64 families, and 20 teachers. The interviews aimed at capturing the different logics of action and strategies on both the demand and the supply sides of the phenomenon. Results were analyzed using categories that had been identified through review of literature on quasi-markets in education conducted prior to the field study.

While this overall research design cannot provide exact assessments of the causal linkages in figure 1 or a strictly representative portrait of the situation of schools and families in Valparaiso, let alone Chile as a whole, it can serve as a critical "reality" check on the conceptual bases of PPPs in the country and furnish new perspectives for critique of school choice and other market policies in education.

\section{Demystifying Market Assumptions in Chilean Education}

This section analyzes the application of public choice theory assumptions to education markets in the Chilean education system on the basis of the data assembled. As mentioned, it is beyond the scope of the present article to test all the implicit relations displayed in figure 1. We do, however, focus on the most important of them, assessing the validity of the causal linkages involved.

\footnotetext{
${ }^{4}$ Valparaiso is one of the most populous cities in Chile, with around 300,000 inhabitants. In the year 2013, the city had 112 primary schools, of which 39 percent were public, 53 percent private but publicly subsidized, and 8 percent totally private.
} 
We cluster these assumptions into two broad groups, one more related to demand behavior and a second one more related to the supply side of the relationship.

\section{Demand Side: School Choice, Information, and Educational Quality}

The first group of assumptions that we need to unpack are those asserting that information allows choices based on quality criteria, and that well-informed family choices are the main trigger of school competition. According to market theory in education, access to objective and transparent information about the quality of the different providers are necessary for consumers to make accurate decisions. A voucher system needs to promote access to information on school quality to allow families to behave as competent consumers. The purpose of the Chilean government in publishing the SIMCE results is to make information on "the quality" of Chilean schools visible to all members of society but especially to students' families - thereby serving to democratize the educational planning process.

Market advocates tend to think of families as "benefit maximizers" or as educational actors whose decisions are guided exclusively by instrumental rationality. However, international research on school choice demonstrates that this is not always the case (Ball 2003; Hastings et al. 2006; Waslander et al. 2010). For instance, family preferences tend to vary according to socioeconomic status (SES): academic features and test scores are more valued by families with higher SES. In contrast, families with lower SES are less responsive to changes in schools' academic performance. Even in the Chilean case, where a long-standing evaluation and information system is in place and huge government campaigns have been undertaken to encourage families to use it, parental choices are based on multiple factors and manifest "rationalities" that go well beyond SIMCE. ${ }^{5}$ In fact, data on choice criteria in Chile itself support the thesis that SES frames decisively the variability of family decisions on education (see fig. 3).

Figure 3 shows that as family SES increases, distance-to-school becomes a weaker constraint on choice. At the same time, values/religion and academic criteria are more important for families from higher SES. Only 7.1 percent of families from the poorest quintile affirm that academic excellence and SIMCE results represent their top criterion of choice. By way of contrast, this value is 24.1 percent in the case of families from the fifth or highest SES quintile.

Economists themselves have at times questioned the uncritical understanding of choice as an action uniquely guided by individual utility maxi-

\footnotetext{
${ }^{5}$ The index of socioeconomic status (SES) used in this analysis was constructed on the basis of four variables included in the SIMCE database: level of family income, father's education, mother's education, and number of books at home. The weight of each variable was calculated by using categorical principal component analysis method.
} 


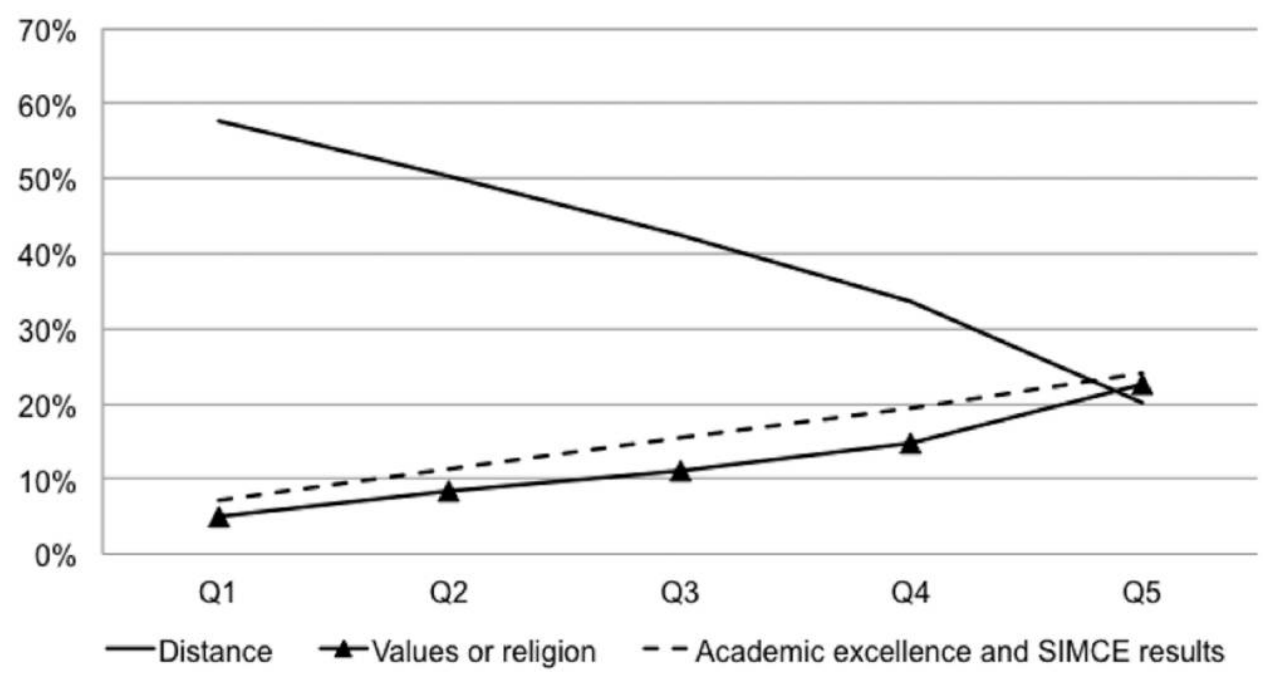

FIG. 3.-First reason for school choice by SES quintiles. SouRCE.-Authors from SIMCE (2011).

mization (Berg 2003; Gauri and Vawda 2003). They acknowledge that choice may change over time - what is technically called the "time-inconsistency problem" in the structure of preferences (Berg 2003). They also acknowledge that the supposed benefits that public choice theory associates with increasing choice possibilities (e.g., secured by vouchers) may face "principalagent problems" (Gauri and Vawda 2003). ${ }^{6}$ In this case, children and their parents constitute the "principal" party, and schools represent the "agent." Though by their enrollment decisions families contract for school services on the assumption (or hope) that the schools in question will treat maximizing children's learning outcomes as their clear priority; in fact, schools often have other interests and agendas that may be concealed from their "clients" (Gauri and Vawda 2003). Economic theory identifies "asymmetric information" as the main factor underlying the principal-agent problem in school choice: the agent may know distinctly more about the possible transactions, trade-offs, and outcomes involved than the principal and so be much better placed to give an appearance of compliance with the terms of the agreement while in fact putting its own interests first. The degree of asymmetry, moreover, differs by with the SES of client families. While top quintile SES families may be relatively fluent in school data and procedures, lack

\footnotetext{
${ }^{6}$ Principal-agent is a political science term for situations where one party (the "agent") is engaged to achieve the interests of another (the "principal") but is often motivated to achieve its own interests in the transaction and short-change the true stakeholder.
} 
of information or difficulties in interpreting it correctly are the main barriers experienced by the most disadvantaged families in making the "right choices." (Schneider et al. 2006).

However, in contrast with this deficit theory interpretation of school choice behavior, our research shows that families with different backgrounds in fact value different school characteristics. These preferences are related to their socioeconomic background but do not necessarily depend on their level of familiarity with standard information sources such as the SIMCE. Thus, in some cases, if the SIMCE is not used as a resource for choosing the best option, it is because families are looking for other school attributes such as discipline or religious values that are absent from the SIMCE database, not because they are ignorant of it.

INTERVIEWER: Did you check SIMCE results when you were looking for a school?

Mother: No, I didn't care about the SIMCE, actually. I really looked for security for my son, the type of teachers, and a space in which he could be comfortable. (Subsidized free private school)

INTERVIEWER: What did you find in this school when you were looking for an alternative for your child?

MотнеR: I liked the teacher training, the structure of the school, its discipline, the fact that it is a religious school, because our family is also Catholic. I especially liked the training and the moral values given to schoolgirls. That's what I liked about this school and that's why I came here. (Subsidized free private school)

Even school managers are aware of the fact that the SIMCE may not be the most crucial influence on school choice. A manager from a subsidized private school whom we interviewed pointed out the paradoxical coexistence, in the same year, of a drop in his school's SIMCE results with a significant increase in demand: "The SIMCE is not the most important thing that families look for. Actually, last year we went down in the SIMCE, and we increased enrollment by 40 students" (principal, subsidized mediumcost private school).

Instead of asymmetric information, what our interviews with Chilean families principally reveal is the prevalence of a highly varied range of school attributes valued by them. Families - including poor families - quite simply value different school characteristics, whatever their level of knowledge of the system. Among these preferences, school composition stands out since many families are concerned to avoid their children having contact with specific social groups (Saporito 2003). Schneider et al. (2006) found that, during the school choice process, 87 percent of Chilean families only consider schools with students whose socioeconomic characteristics are simi- 
lar to their own. Our own data also show that a number of parents discard schools for this same reason:

INTERVIEWER: Is this the school you chose as your first option? Did you check other schools?

Father: No, I chose this one because. . . There's a school closer to my home, but I don't like it. It's a municipal school, and I dislike the children that go there. (Subsidized medium-cost private school)

School size also has an influence on the schooling decisions of families. Small schools tend, for example, to be associated with a warmer and friendlier atmosphere.

INTERVIEWER: Is this the school you choose as your first option?

MотнеR: Yes, because it's a small school and closer to my home. (Subsidized free private school)

INTERVIEWER: Why did you choose this school?

Mother: Because it's a small school, with not many children. The quality is good and I like it. The smaller the school, the more parents can know it, the more contact with teachers. We are like a family. (Subsidized free private school)

Of course, the satisfaction of preferences may be limited by the nature of education supply in the area in question (Thieme and Treviño 2013). When this is the case, poor families must adjust their initial structure of valued attributes to match the geographical particularities and limitations of their local education market. The geographical constraints on choice in Chile have been extensively examined by Elacqua (2012), who shows that the majority of students in low-performing schools either have no better alternatives close to their homes or are constrained in their mobility among schools by selection processes and economic restrictions.

Other limitations on choice derive from the realities of family budgets: some households simply cannot cover the fees that subsidized private schools charge. The following interview reflects this idea clearly:

INTERVIEWER: What type of schools did you check before this one?

Mother: I saw some of them not very far from home; they are private schools. But they were too expensive, and I can't afford them.

INTERVIEWER: And what about the other schools you checked? Did you exclude them because of the cost?

Mother: Yes. That was the only reason. (Subsidized free private school) 
Overall, our data show that families' preferences and choice criteria are highly variable in real education settings. Different preference structures, economic constraints and geographical limitations undermine competition dynamics (or the "race for excellence") among schools in education quasimarkets. This implies, among other things, that schools can improve their "market position" by responding to different families' preferences without having necessarily to improve their academic performance. In other words, family choices do not necessarily impel improvements in school quality but instead produce a range of different responses by schools to the shape of educational demand. We explore this topic further in the next section.

Supply Side: Competition, Educational Quality, and School Diversification

To gain a better understanding of how education markets work, demandside analysis must be complemented by analysis of the behavior of education providers. The theory of education markets posits that it is providers' response in the competition to satisfy consumers' demand that ensures the highest level of market efficiency. There are two sides to this assumption: The first is encapsulated in the assertion that "school competition generates higher levels of efficiency and quality"; the second concerns the assumed levels of innovation and diversification associated with higher levels of competition.

Before carefully scrutinizing these assumptions, we examine first whether and to what extent competition actually occurs. Under market theory one expects that numerous providers of the same service operating in the same territory will guarantee vibrant competition. This should be the case in the Chilean system, which is characterized, especially in urban areas, by massive educational supply in terms of the number of schools. To take one representative example, the small neighborhood in Valparaiso that we studied had 10 schools operating within very close proximity; four of them were within 500 meters of each other on the same street. This would seem like a very high level of "objective competition" in the school market. To our surprise, however, school principals did not generally perceive this level of competition or interpreted it as only involving schools very similar to their own in characteristics and market position (see also Gewirtz et al. 1995). All the principals we interviewed were completely aware of the prevailing market segmentation in Chilean education, a phenomenon recently highlighted by a number of studies. ${ }^{7}$ One principal offered, for example, the following comment on competitive pressures: "I think that in geographic terms ... in each place there are one or two schools ... We should have to steal students from [Public School 02] and beyond . . . in that space. But to be honest there is so much good word-of-mouth, because our student population comes by itself" (Principal, public school). (2014).

${ }^{7}$ See, e.g., Mizala and Torche (2012); Elacqua at al. (2013); Valenzuela et al. (2014); Zancajo et al. 
The fact that perceived competition is far below what an outside observer might assume to be its "objective" level has real implications for school dynamics. Segmentation in the market for educational services in fact operates to limit competition (Fitz et al. 1997).

This does not mean that competition dynamics are entirely absent from the Chilean education market - far from it. However, competition takes place at very different levels of intensity, and in very different terms from those predicted by public choice theory. Under public choice theory, we would expect to observe what Van Zanten (2009, 86; based on the evidence presented by Gewirtz et al. 1995) denominates as "first-order competition" in student recruitment, which involves each provider attempting to secure the highest number of students from the total pool in a local education market. In real education markets, however, providers have stronger incentives to go for "second-order competition" (Van Zanten 2009, 86), which refers to efforts to recruit specific categories or strata of students - such as those who are more academically able or have a positive attitude toward learning and school norms.

Schools are aware of the fact that such attributes (both academic and social) affect the circumstances in which they provide educational services and so inevitably influence their academic results. Thus, in quasi-market frameworks where students' test results have a direct effect on market positioning, schools will tend to compete to attract those students who are congruent enough with their particular ethos to help them build comparative advantage. This is especially true in those cases, like the Chilean one, where performance is linked to state financial incentives for teachers. In these situations, schools in fact select students more often than students / families choose schools. Second-order competition is both promoted by segmented education markets and contributes to reproducing school segmentation and segregation (Elacqua 2012).

Table 1 shows how common student selection practices are in Chilean schools. The data presented summarize the main enrollment requirements in different categories of schools, as reported by parents and demonstrate

TABLE 1

School Enrollment Requirements as Reported by Parents (\% of Parents Responding to Each Requirement)

\begin{tabular}{|c|c|c|c|}
\hline & Public & Subsidized Private & Private \\
\hline Evaluation of preschool education & 24.2 & 37.2 & 47.3 \\
\hline Certificate of grades at the previous school & 35.5 & 42.6 & 33.9 \\
\hline Certificate of baptism or religious marriage & 6 & 13.7 & 31.1 \\
\hline Certificate of salaries & 2.6 & 7.4 & 4.8 \\
\hline Interview with parents & 16.8 & 40.3 & 79.8 \\
\hline Observation of students' behavior in-class & 1.6 & 7 & 33.1 \\
\hline The student must take a written exam or entrance test & 8.5 & 45 & 58.8 \\
\hline Total number of observations (n) & 80.153 & 106.960 & 15.222 \\
\hline
\end{tabular}

Source.-Authors, from SIMCE (2011). 
that schools in fact apply a range of admission criteria that differ substantially by type of school involved - despite the fact, mentioned above, that student selection is illegal in Chilean primary education.

The student sorting and selection process can be understood as a shortcut to quality. Schools do not compete as much by improving their educational services or raising their quality standards as much as they do by screening their students on different sets of criteria. Recruitment practices, along with expulsion patterns, turn out to be highly "strategic" phenomena in many schools. As Hsieh and Urquiola (2006) demonstrate, student selection processes are one of the main determinants of the higher academic performance of private schools in Chile.

Overall, what competition generates is not straightforward incentives for better quality but rather strategies for finding and attracting the students that best match the profile and competitive advantage of different categories of schools. In this context, the fees that schools charge are more the result of a deliberate strategy to segment the market than the result of a calculation of the objective value of the services offered. In other words, price-in addition to selective admissions policies - can be used by schools to exclude undesired students and thereby increase the homogeneity and performance of their enrollment.

\section{Do Quasi-Markets Lead to Educational Diversification and Innovation?}

The second assumption on the supply side in educational markets is related to the relationship between competition on the one hand and education innovation and diversification on the other. Market pressure is expected to make schools more innovative and diverse and, by doing so, to generate a more varied supply of educational and curricular services. In other words, by market premises, competitive pressure should produce horizontal segmentation in the school market, understood as the production of a greater number of pedagogical and/or curricular options (Lubienski 2006). This assumption is largely contradicted, however, by the fact that, as just shown, market rules tend to generate more vertical than horizontal segmentation and the former tends either to alter or to prevent the latter. This effect was already noted in the 1994 OECD publication, School: A Matter of Choice, which concluded that "Demand pressures alone are rarely enough on their own to create . . . diversity. . . U Under a uniform model of schooling, choice is more likely to reinforce educational hierarchies" (OECD 1994, 80).

Vertical segmentation, or "hierarchization," is based first and foremost on student enrollment and the composition of schools. Once this type of segmentation has occurred and the position of the schools in the hierarchy has been well established, there are fewer chances for schools to innovate and fewer incentives for them to respond to new clients' demands. When this type of segmentation prevails, schools often end up defining and rationalizing 
their educational strategy and model as a function of the market niches that remain available to them, or as a reaction to their immediate socioeconomic context. Overall, a school's room for manoeuvre is especially limited when its reputation is heavily anchored in the local space (see Van Zanten 2009). As the principal of a free public school remarked to us: "We have improved a little, but it's hard because there are many factors that have to be considered, such as student attendance, children who are absent for nonacademic reasons, such as the mother being asleep. . . . These are moms who are not very committed to education."

In evident contradiction to the predictions of public choice theory, private schools are not necessarily the main drivers of innovation. On the contrary, according to Lubienski (2006, 333), "Where educational innovations are occurring, they are often the result of bureaucratic or publicpolicy interventions, not market forces." On the basis of the theory of monopolistic competition, this author argues that diversification is one of the strategies developed by educational providers to reduce the level of competition to which they are exposed-not to increase it. Moreover, the strategy is frequently based on symbolic innovations (in marketing, branding and other image domains) rather than on substantive pedagogical and/or curricular changes. Schools that are successful enjoy some degree of monopoly control (Lubienski 2006). In Chile, it is quite common for schools to change their traditional Spanish-language name for an English one or to adorn themselves with symbols - such as distinctive uniforms - that are associated with elite schools (Espinola 1993).

In the Valparaiso neighborhood that we analyzed, there are a few schools that highlight their "curricular project"-usually schools with alternative pedagogies - and consider it as a key element of their success. However, it is also true that curricular innovation may work as an indirect way of screening for motivated families, whether they are from the highly-educated middle class or the highly aspirational segments of the lower class. The line between pedagogical innovation and marketing may at times be very thin. In fact, symbolic distinction strategies are frequently used by schools to improve their market position and to attract new demand. For example, the principal of a private school in our sample admitted that he uses selection tests, not because he needs them (in fact, his school had weak enrollment) but as a way to burnish the school's image:

INTERVIEWER: Are you interested in a particular student profile?

PRINCIPAL: The most important thing is that they have a clear vision of what they want to achieve. That's enough for me. . . However, I think that next year we are going to introduce selection tests. Why? Families to some extent. . . . this circulates by word of mouth, and they would say "not everyone can go to this school, you need something else. . . " You see? It is a bit like marketing? (Private school) 
The reasoning of this Chilean principal is more than anecdotal. As Ball $(1993,7)$ notes in relation to the British quasi-market model, schools "are also using the option of exclusion more readily in order both to rid themselves of 'difficult' students and to demonstrate to potential clients that discipline and safety are taken very seriously." And, he adds, "Selection is, and will increasingly become, a 'selling point': what you get is who you go with."

Why, though, would market rules promote educational standardization? Different mechanisms can be identified here. The first reason for standardization to occur in quasi-market frameworks is that many of the schools that aim to become competitive attempt to emulate institution that provide a highly traditional education. Thus, they tend to offer a traditional academic curriculum giving access to higher education, which they know is the top priority of most families (Adnett and Davies 2000).

Second, the external exams that are supposed to promote competition end up standardizing educational services and promoting curricular conformity. External evaluations and the resulting rankings therefore have the potential to undermine efforts to promote a more diverse and differentiated curricula and so to create situations where "schools look ... more and more like each other" (Levin 1997, 259). In Chile, the pressure generated by external evaluation policies is undoubtedly having this effect. In all the schools analyzed, "teaching to the test" is strongly embedded in the organizational culture and curricular priorities of the institution. Every week, numerous class hours are dedicated to training students to become skilled test-takers (some schools even have a subject called "SIMCE"); the best teachers are assigned to teach subjects evaluated by the SIMCE, and a significant portion of the school budget is allocated to hiring consultancy firms that provide SIMCE simulations. Teaching to the test is an expanding practice in Chile, which does not mean that the pressure that the SIMCE generates sits comfortably with the teachers.

\footnotetext{
When I was offered the fourth grade, they automatically gave me the SIMCE, and I was not ready to work on the SIMCE. In fact, I don't agree with the SIMCE. . . . but we are part of the system and we have to do it. (Interview teacher 01, Subsidized private school A)

It is very stressful to work on a course with the SIMCE because there are many goals to achieve, many demands. We are subordinated to the results when giving this type of course. Personally, I don't like working with SIMCE groups; you're constantly struggling, and they expect results. (Interview teacher 02, Subsidized private school $\mathrm{B}$ )
}

Third, educational markets produce an additional paradox that limits diversification: In competitive frameworks, schools that are experiencing excess demand and/or those that are performing well in rankings should have 
the resources to fund innovation, but conversely little incentive to do so (because they are already doing well playing by the existing rules of the game). At the same time, those schools that should be more willing - and have greater need-to innovate, do not have the resources to do so due to insufficient demand. These same resource-poor schools also have the kinds of pupils who take less well to experiments with innovative pedagogies, and their more innovatory staff tend therefore to quit in favor of better-resourced or more prestigious institutions (Adnett and Davies 2000). In the Chilean case, the fact that schools are legally authorized to charge higher fees - and that more successful schools often do this-further increases the fragmentation effect.

Finally, competition among schools faces additional constraints that are due to the nature of the educational field itself and that make it even less likely that the practice will lead to diversification and continuous innovation. As Adnett (2004) notes, some of these limitations stem from the uncertainty surrounding which specific modes of teaching and learning are most effective or from the difficulty of transferring successful experiences from one context to another. An innovation that may be successful with one set of teachers and pupils may not be successful with another set that does not possess the same characteristics - a caveat that becomes more obvious in highly segmented education systems like the Chilean one.

\section{Conclusion: Things Left Unsaid in Educational Quasi-Markets}

Our study focused on the Chilean education system as a paradigmatic case of the application of market mechanisms to educational supply. Our research approach, inspired by the practice of realist evaluation, may be particularly useful in demystifying public choice theory predictions about the superiority of market mechanisms in education. By taking actors' behaviors and responses not as given or solely guided by instrumental rationality, a realist evaluation perspective opens the space to observe other motivations, rationalities, and translation processes that govern the way in which subjects react to information and incentives within education quasi-markets.

Our research echoes findings from other scholars about the Chilean case (e.g., Hsieh and Urquiola 2006; Mizala and Torche 2012; Elacqua at al. 2013) and, like them, demonstrates that arguments for the superiority of quasimarket mechanisms are far from irrefutable. However, our goal in this article has not been to "measure" the exact effects of quasi-markets in education but rather to analyze how market mechanisms work in real situations and how a number of factors, usually absent from discussion of public choice theory, alter relevant aspects in educational actors' behaviour, including decisions about school choice, exit, price-setting, and selection.

When observing market mechanisms operating in real educational settings, the most relevant research question is not whether these mechanisms do or do not work, but whether and under what circumstances market rules 
are powerful enough to shape actors' behavior. Actors' responses are conditioned by a large number of factors that can affect and can even counteract the rules defined by the market; and choice is a good case in point. As our work demonstrates, after more than 30 years of persistent pro-school choice policies in Chile, family decisions are neither irrefutably based on "objective information" nor automatically responsive to traditional indicators of school quality.

The fact that market rules are neither enforced nor "obeyed" in the ways their advocates assume does not cancel their effect or make them harmless. They do alter the educational landscape, although in ways that are different from the predictions of public choice theory and the expected responses of education agents. As the Chilean case clearly indicates, actors' strategies, "logics of action" and responses to incentives do not take form in a vacuum, but are rather born in social and institutional settings strongly shaped by market rules.

One of the most obvious effects of the application of market mechanisms to education is the vertical segmentation of supply and the resulting academic and social segregation. What market rules mostly do is shape agents' responses in a way that increases social and academic differentiation within the system. Providers have large incentives to compete for the best students and to exclude those who can adversely affect their results and reputation. On the demand side, a large number of families look for their "social segment" in the education market, in most cases to avoid schools where the poorest are enrolled. However, as the Chilean case shows, not all families are in a position to escape what Chubb and Moe (1990) call the "schools that falter" due to financial, geographical or social constraints. The well-stocked and highly diversified education market conceived in quasi-market ideology just does not exist for everyone, due to the numerous impediments to choice and the incentives that schools experience for getting rid of the academically weakest students. These students end up enrolling in schools - usually public ones - whose performance then suffers but that do not close down as a consequence, precisely because the process facilitates the concentration of underachievers.

The effects of these dynamics on social justice and inequality of opportunities are multiple and devastating. There is a negative peer effect as a result of school segregation, which is seldom mentioned by market advocates. For every potentially good student that is able to "escape" a bad school and to enroll with high-performing peers, there is a loss of that student in a school that remains full of low performers. For market advocates, these exit dynamics represent a zero-sum game - that is, a process where the losses experienced by some are fully compensated by the benefits experienced by others. However, the peer-effect losses that these dynamics generate destroy that balance and have the potential to undermine the aggregate quality of the 
education system as well as the educational opportunities of those students that are not able to "escape."

Finally, the recent history of the Chilean education system serves as a template for testing the economic theory of second-best markets in education, which suggests that "when features of particular sectors preclude puremarket arrangements, attempts to impose more market-like models may lead to less-optimal and even perverse outcomes - with no a priori way of knowing the likely effects" (Lubienski 2006, 334). Clear evidence of market failure in the Chilean education system - a system now characterized by high inequality and few significant improvements in overall performance-has compelled the Chilean state to develop policies for correcting market imperfections and creating external incentives for schools to compete and become more efficient. These policies include new systems of performance-based teacher salary supplements, new information dissemination programs to ensure that families get full information on the SIMCE results, and-significantly - the introduction of an extra voucher system for schools enrolling vulnerable students. ${ }^{8}$

As a consequence, Chile - one of the purest market systems in education-is gradually being transformed into a second-best education market. It is of course too early to assess how these new measures will affect the system's equity and effectiveness. However, a realist evaluation perspective suggests that optimal results can hardly be expected because second-best options do not alter the importance and the weight of other factors shaping actors' responses. Lubienski's (2006) examples of unexpected mechanisms associated with this new generation of incentives can clearly be applied to the Chilean case. Schools can be invited to become even more selective, but innovation will hardly occur in a system that becomes even more oriented toward "teaching to the test." Providers' tactical moves may once again alter the effect of new policies and contradict what market rules would predict for system performance improvement. The most convinced market advocates may still attribute the erratic functioning of the Chilean public-private partnership to the (increasing) intervention of the state. To them, the roots of socially and historically situated educational problems seem always to be related to too much state and too little market.

\section{References}

Adnett, N. 2004. "Private-Sector Provision of Schooling: An Economic Assessment." Comparative Education 40 (3): 385-99.

Adnett, N., and P. Davies. 2000. "Competition and Curriculum Diversity in Local Schooling Markets: Theory and Evidence.” Loumal of Education Policy 15 (2): 157-67.

\footnotetext{
${ }^{8}$ Ley de Subvención Preferencial (SEP)—Ley 20.248 (Preferential School Grant Act).
} 
Ball, S. J. 1993. "Education Markets, Choice and Social Class: The Market as a Class Strategy in the UK and the USA." British Journal of Sociology of Education 14 (1): 3-19.

Ball, S. J. 2003. Class Strategies and the Education Market: The Middle Classes and Social Advantage. London: Routledge.

Ball, S. J., M. Maguire, and A. Braun. 2012. How Schools Do Policy: Policy Enactments in Secondary Schools. London: Routledge.

Ball, S. J., and C. Maroy. 2009. "School's Logics of Action as Mediation and Compromise between Internal Dynamics and External Constraints and Pressures." Compare 39 (1): 99-112.

Berg, N. 2003. "Normative Behavioural Economics." Journal of Socioeconomics 32 (4): 411-27.

Bowe, R., S. J. Ball, and A. Gold. 1992. Reforming Education and Changing Schools. Case Studies in Policy Sociology. London: Routledge.

Buchanan, J. M., and G. Tullock. 1999. The Calculus of Consent: Logical Foundations of Constitutional Democracy. Indianapolis: Liberty Fund.

Chakrabarti, R., and P. E. Peterson. 2009. School Choice International: Exploring PublicPrivate Partnerships. Boston: MIT Press.

Chattopadhay, T., and O. Nogueira. 2013. "Public-Private Partnership in Education: A Promising Model from Brazil." Iournal of International Develobment 26 (6): 875-86.

Contreras, D., S. Bustos, and P. Sepúlveda. 2007. "When Schools Are the Ones That Choose: The Effect of Screening in Chile." Social Science Ouarterly 91 (5): 1349-68.

Chubb, J. E., and T. M. Moe. 1990. Politics, Markets and America's Schools. Washington, DC: Brookings Institution.

Elacqua, G. 2012. "The Impact of School Choice and Public Policy on Segregation: Evidence from Chile." International Journal of Educational Develobment 32:444-53.

Elacqua, G., P. Montt, and H. Santos. 2013. "Evidencias para eliminar-gradulamente-el Financiamiento Compartido.” Instituto de Políticas Públicas. Claves de Políticas Públicas, 14.

Espinola, V. 1993. "The Educational Reform of the Military Regime in Chile: The System's Response to Competition, Choice, and Market Relations." Unpublished $\mathrm{PhD}$ dissertation.

Fitz, J., D. Halpin, and S. Power. 1997. “'Between a Rock and a Hard Place': Diversity, Institutional Identity and Grant-Maintained Schools.” Oxford Review of Education 23 (1): 17-30.

Friedman, M. 1994. "The Case for Choice." In Voices on Choice: The Education Reform Debate, ed. K. L. Billingsley. San Francisco: Pacific Research Institute.

Gauri, V., and A. Vawda. 2003. "Vouchers for Basic Education in Developing Countries A Principal-Agent Perspective.” Policy Research Working Paper no. 3005, World Bank, Washington, DC.

Gewirtz, S., S. J. Ball, and R. Bowe. 1995. Markets, Choice and Equity in Education. Buckingham: Open University Press.

Glennerster, H. 1991. “Quasi-Markets for Education?” Economic Iournal 101 (408): 1268-76.

Glewwe, P. (2014). Education Policy in Developing Countries. Chicago: University of Chicago Press. 
Hastings, J. S., T. J. Kane, and D.O. Staiger. 2006. "Parental Preferences and School Choice Competition: Evidence from Public School Choice Program.” NBER Working Papers Series 11805.

Hoxby, C. M. 2000. "Does Competition among Public Schools Benefit Students and Taxpayers?" American Economic Review 90 (5): 1209-38.

Hsieh, C. T., and M. Urquiola. 2006. "The Effects of Generalized School Choice on Achievement and Stratification: Evidence from Chile's Voucher Program." Lournal of Public Economics 90:1477-503.

Klees, S. J. 2008. "A Quarter Century of Neoliberal Thinking in Education: Misleading Analyses and Failed Policies." Globalisation. Societies, and Education 6 (4): 311-48.

Lawson, T. 2009. "Applied Economics, Contrast Explanation and Asymmetric Information." Cambridge Journal of Economics 33:405-19.

Le Grand, J. 1991. "Quasi-Markets and Social Policy." Economic Journal 101 (408): $1256-67$.

Levin, B. 1997. "The Lessons of International Education Reform." Journal of Education Policy 12 (4): 253-66.

Levin, H. M. 1999. "The Public-Private Nexus in Education." American Behavioral Scientist 43 (1): 124-37.

Levin, H. M., I. Cornelisz, and B. Hanisch-Cerda. 2013. "Does Educational Privatisation Promote Social Justice?” Oxford Review of Education 39 (4): 514-32.

Lubienski, C. 2006. "School Diversification in Second-Best Education Markets." Educational Policy 20 (2): 323-44.

Lubienski, C. 2014. "Re-making the Middle Dis-Intermediation in International Context." Educational Management Administration and Leadership 42(3): 423-40.

Marchal, B., S. van Belle, J. van Olmen, T. Hoerré, and G. Kegels. 2012. "Is Realistic Evaluation Keeping Its Promise? A Review of Published Empirical Studies in the Field of Health Systems Research." Evaluation 18 (2): 192-212.

Mizala, A., and P. Romaguera. 2004. "School and Teacher Performance Incentives: The Latin American Experience." International Journal of Educational Development 24 (6): 739-54.

Mizala, A., and F. Torche. 2012. "Bringing the Schools Back In: The Stratification of Educational Achievement in the Chilean Voucher System." International Iournal of Educational Development 32:132-44.

Mueller, D. C. 1979. Public Choice. Cambridge: Cambridge University Press.

OECD. 1994. School: A Matter of Choice. Paris: OECD.

OECD. 2012. Public and Private Schools: How Management and Funding Relate to Their Socio-Economic Profile. Paris: OECD.

Olson, M. 1965. The Logic of Collective Action: Public Goods and the Theory of Groups. Cambridge, MA: Harvard University Press.

Patrinos, H. A, F. B. Osorio, and J. Guaqueta. 2009. The Role and Impact of PublicPrivate Partnerships in Education. Washington, DC: World Bank.

Pawson, R. 2006. Evidence-Based Policy: A Realist Perspective. Thousand Oaks, CA: Sage.

Pawson, R., and N. Tilley. 2004. "Realistic Evaluation." In Encyclopaedia of Evaluation, ed. S. Matthieson. Thousand Oaks, CA: Sage.

Porter, S. 2015. "The Uncritical Realism of Realistic Evaluation.” Evaluation 21 (1): $65-82$. 
Rouse, C. E., and L. Barrow. 2009. "School Vouchers and Student Achievement: Recent Evidence and Remaining Questions." Annual Review of Economics 1:17-42.

Saporito, S. 2003. "Private Choices, Public Consequences: Magnet School Choice and Segregation by Race and Poverty." Social Problems 50 (2): 181-203.

Scheneider, M., G. Elacqua, and J. Buckley. 2006. "School Choice in Chile: Is It Class or the Classroom?" Lournal of Policy Analvsis and Management 25 (3): 577-601.

Thieme, C., and E. Treviño. 2013. "School Choice and Market Imperfections: Evidence from Chile." Education and Urban Societs 45 (6): 635-57.

Tooley, J. 1993. A Market-Led Alternative for the Curriculum: Breaking the Code. London: Institute of Education.

Valenzuela, J. P., C. Bellei, and D. De Los Ríos. 2014. "Socioeconomic School Segregation in a Market-Oriented Educational System: The Case of Chile." Lournal of Education Policy 29 (2): 217-41.

van Zanten, A. 2009. "Competitive Arenas and Schools' Logics of Action: A European Comparison." Compare 39 (1): 85-98.

Verger, A. 2012. "Framing and Selling Global Education Policy: The Promotion of Public-Private Partnerships for Education in Low-Income Contexts." Lournal of Education Policy 27 (1): 109-30.

Waslander, S., C. Pater, and M. van der Weide. 2010. "Markets in Education: An Analytical Review of Empirical Research on Market Mechanisms in Education." OECD Education Working Paper no. 52.

Wößmann, L. 2006. "Public-Private Partnership and Schooling Outcomes across Countries." CESifo Working Paper Series 1662. http://ssrn.com/abstract $=889519$.

Zancajo, A., X. Bonal, and A. Verger. 2014. "Mercados educativos y segmentación de la oferta escolar: Efectos sobre las desigualdades educativas en Chile." Témpora: Revista de historia y sociología de la educación 17:17-30. 